\title{
Evaluation of Antibacterial Effect of Cucurbita pepo (Yakten) Extracts on Multi-antibiotic Resistance Bacterial Strains Isolated From Human Urinary Tract Infections
}

\author{
Abdulrhem T. AL-Ghazal \\ Department of Biology \\ College of Science \\ University of Mosul \\ bakurius@yahoo.com
}

(Received 18/9/2011 ; Accepted 21/11/2011)

\begin{abstract}
The aqueous and methanolic extracts of Cucurbita pepo, were used as antimicrobial activity against multi-antibiotic resistance strains (Escherichia coli, Staphylococcus aureus, Klebsiella pneumonia, and Proteus mirabilis) which were isolated biochemically from human urinary tract infections. The in vitro antimicrobial activity was performed by using Kirby-Bauer diffusion. The methanolic extracts of Cucurbita pepo fruit-cortex showed for the first time a high to moderate antimicrobial activity against Staphylococcus aureus and Escherichia coli respectively whereas the aqueus extract showed a moderate effect against Staphylococcus aureus only. Weak antimicrobial activity was seen on Klebsiella pneumonia, and Proteus mirabilis using both extract. Using core fruit methanolic and aqueus extraction showed no effect on any pathogenic bacteria. Whole fruit methanolic extract gave moderate and low antimicrobial effect on Staphylococcus aureus and Escherichia coli respectively. The results concluded that the application of Cucurbita pepo cortex extract against human multiresistant urinary tract pathogens may represents a new source as adjuvant to antibiotics for effective treatment of bacterial urinary tract infections.
\end{abstract}

Keywords: Antimicrobial activity, methanolic extract, Escherichia coli, Staphylococcus aureus, Klebsiella pneumonia, Proteus mirabilis, Cucrbita pepo.

\section{قيميم التأثير المضاد لهنخاص نبلت اليتلن Cucurbita pepo عل البكتربا المتعدة المقاومة المضادل الحيوبة والمعزولة من النتانلت الجهاز البولي للانسلن}

\section{المالغ}

م استخدلم المستخلص المائي ومستخلص الميثانول لنبلت اليطن Cucurbita pepo بوصفه علملاً

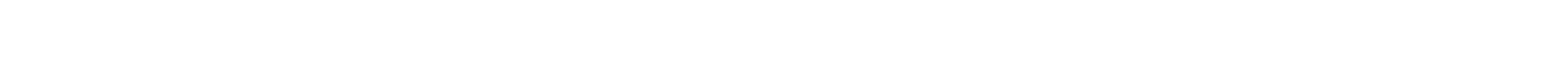
البولي للإنسان ( Escherichia coli, Staphylococcus aureus, Klebsiella pneumonia, and Proteus 
(mirabilis). لختبرت الفعالية المضادة للنبلت تجاه البكتريا بلستخدلم ققنية Kirby-Bauer diffusion. ظٔظهر

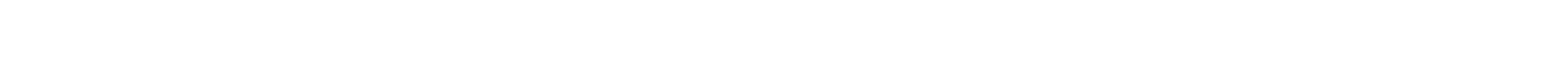
Staphylococcus aureus

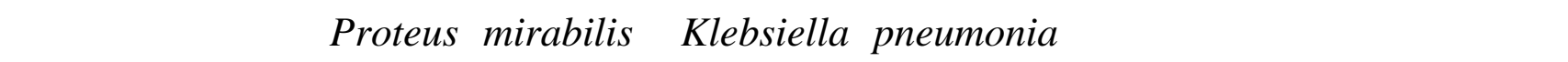

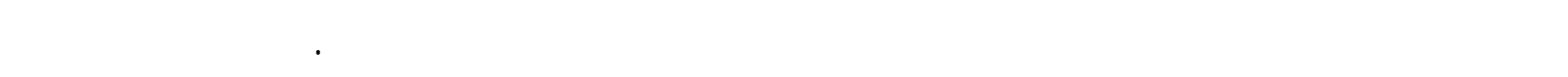

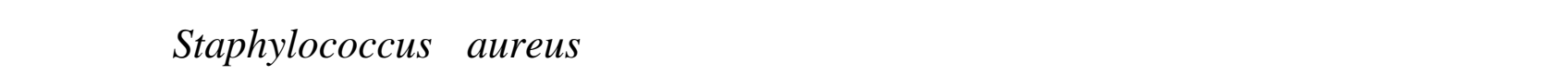
Escherichia coli

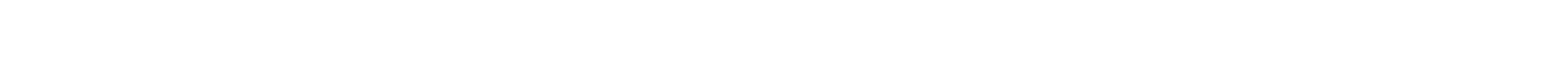

\section{INTRODUCTION}

The numbers of pathogenic multiresistant bacterial strains that carry resistance to many antibiotics were increased gradually. This increasing creates an emergent need to produce new antimicrobial agents. The most important antibiotic sources is the plants which provide us with different antimicrobial agents. Secondary metabolites of plants provide efficient pharmaceutical agents such as terpenoides, xanthones, benzophenones, coumarins, alkaloids, saponins, tannins, flavonoids, glycolipid, and galactolipids (Belguith et al., 2010). Many parts of the plant (leaves, roots,flowers, whole plants, seeds, fruits and stems) were examined as antimicrobial agents in many researches against different pathogenic bacteria (Maeda et al., 2009).

Researchs carried out in last few decades have validated several claims of the uses of traditional medicine plants. Popularity of Cucurbita pepo in various systems of traditional medicine for several ailments (antidiabetic, antihypertensive, antitumor, immunomodulation, antibacterial, antihypercholesterolemia, intestinal antiparasitic, antiinflammation, and antalgic) focused the investigators' attention on this plant (Fu et al., 2006).

Cucurbita pepo gaves scavenging capacities due to the presence of flavonoid and phenylpropanoid glycoside-compounds known as potential hydrogen donors and radical scavengers. The scavenging activities for $\mathrm{OH}$ radical may be due to phenolic substances which stimulate hydrogen donating ability of hydroxyl substitutions (Dorman et al, 2003). Leman et al., showed in 2007 that Cucurbita pepo also showed antioxidant capacities. The carotenoids of Cucurbita pepo have been investigated for some time, but the studies were mostly limited to provitamin A. Carotenoids in terms of human health, reduce the risk of degenerative diseases such as cancer, cardiovascular diseases,cataracts, and macular degeneration, thus the importance of determining the vitamin A-inactive carotenoids became evident (Godoy and Rodriguez-Amaya, 1998). Other important contents in Cucurbita pepo are Oleic acid which is significantly the most concentrated followed by linoleic and palmitic acid. With the exception of magnesium and manganese, all other endogenous mineral contents varied significantly among seed samples. Potassium, 
magnesium, and calcium were the most prevalent minerals, respectively (Ahmed et al., 1996).

Other study revealed that cucurbitaceae plants are a great source of folic acid and are often prescribed for those who are lethargic, anemic or pregnant (Landrum and Bone 2001). In addition to that, it was investigated that Cucurbita pepo has phenolic contents with antioxidant capacity (Leman et al., 2007). This plant also contains carotenoids which used as provitamin A carotenoids, for human health, that is, reduction of the risk of degenerative diseases such as cancer, cardiovascular diseases, cataracts (Godoy and Rodriguez, 1998).

Chromatographic purification of Cucurbita pepo fruit extracts showed that there is many important components such as: triglyceride fatty acid mixture, tetrahydro-thiophene, linoleic acid, calotropoleanly ester, cholesterol oleanen-3-ol. All components revealed antimicrobial, antiviral and antitumour activities (Badr et al., 2010). No reports refer to plant fruit cortex as a source for pharmaceuticals.

The current study investigated that the antimicrobial components of three parts of Cucurbita pepo are cortex, core and whole fruit against multi-antibiotic resistance strains (Escherichia coli, Staphylococcus aureus, Klebsiella pneumonia, and Proteus mirabilis) which were isolated biochemically from human urinary tract infections.

\section{Samples}

\section{MATERIALS AND METHOD}

The Fresh fruits of Cucurbita pepo used in this work are taken from a local farm in Mosul city and divided into three parts; cortex, core and whole fruit. For effective extraction of the plant material, a freeze-drying method was performed. Freeze-drying is known to have a high extraction efficiency because ice crystals formed within the plant matrix can rupture cell structure, which allows exit of cellular component and access of solvent, and consequently better extraction (Chan et al., 2009).

\section{Preparation of extract}

Each part of fruit was extracted with $70 \%$ alcoholic and distilled water in a specific glass compressor (Germany) for 10 minutes using $5 \mathrm{gm}$ of fruit $/ 5 \mathrm{ml}$ of extract solution. The whole extract was then filtered with the help of whatman no. 4 filter paper.

The collected solvent was then evaporated to dryness with rotary vaccum evaporator at 40 ${ }^{\circ} \mathrm{C}$ to afford a thick residue. The thick residue was then converted in dried powder in desiccators. This dried mass was dissolved in alcohol and in aqueous to get $20 \mathrm{mg} / \mathrm{ml}$ concentration of extract (Obi and Nwanebu, 2009).

\section{Test bacteria}

Four multiresistant bacterial strains (Staphylococcus aureus, Escherichia coli, Proteus mirabilis and Klebsiella pneumonia) were isolated biochemically from urine specimens of in-patients and out-patients of General Hospital of AL-Baida city/ Libya and used for antimicrobial activity (Cheesbrough, 2002; Powers, 1991; Cappuccion et al., 1992). Cultures identification was carried out by using standard techniques (Udo et al., 2008). The test bacterial multiresistant strains include Staphylococcus aureus as two strains resistant to 12 and 13 antibiotics, two multiresistant strains of Escherichia coli resistant to 13 antibiotics for each, one multiresistant strain of Proteus mirabilis resistant to 12 antibiotics 
and two strains of Klebsiella pneumonia resistant to 12 and 13 antibiotics were used as tested bacteria (Table 1).

\section{Culture media and Antibiotics}

Muler Hinton Agar and Nutrient agar were used for agar diffusion assay. Amoxicillien (Amo) (10mcg, for gram +ve), Gentamycin (C) (10mcg, for gram-ve) were used as control.

\section{Antimicrobial Activity Test}

The Antimicrobial susceptibility testing was done using Kirby-Bauer diffusion technique. The tests were realized by diffusion method using Muller Hilton agar while the antibacterial effect was determined depending on the inhibition area diameter (Nicodim et al., 2009). Two standardized overnight cultures of each strain (containing $10^{8}$ colonyforming units, CFU/ml) were used to flood surface of Muller Hilton agar. The antibiotic discs impregnated in $20 \mathrm{mg} / \mathrm{ml}$ of three extract; cortex, core and whole fruit and the controls (Amoxicillin 10mcg, Gentamycin 10mcg) were then aseptically placed at reasonable equidistance on the inculated plates and allowed to stand for $1 \mathrm{~h}$. The plates were then incubated at $37 \mathrm{C}^{\circ}$ for $18 \mathrm{~h}$ (Ehinmidu, 2003).

\section{RESULTS AND DISCUSSION}

The results revealed that alcoholic and aqueus cortex extract (cxt) of Cucurbita pepo gave high effect on Staphylococcus aureus. Alcoholic extract (Aex) showed a higher effect with a high inhibition zone on bacteria $(16 \mathrm{~mm})$, whereas aqueus extract (aqex) showed a moderate effect $(10 \mathrm{~mm})$ compared with control $(18 \mathrm{~mm})$. For Escherichia coli cxt gave moderate effect on this pathogen (Table 2). Higher effect was noticed using Aex (16mm), whereas Aqex showed lower effect $(4 \mathrm{~mm})$. Aqex or Aex of the cortex showed weak effect on both Proteus mirabilis and Klebsiella pneumonia. Using core fruit extraction (Aqex or Aex) the results showed no effect on any pathogenic bacteria. Whole fruit extract gave moderate antimicrobial effect on Staphylococcus aureus ranged between $6 \mathrm{~mm}$ using Aqex and 8mm using Aex. With Escherichia coli Aqex and Aex gave low antimicrobial effect with $2 \mathrm{~mm}$ of inhibition zone for each extract (Wex and Aex) compared with the control (Figure 1). The same treatment showed no effect on Proteus mirabilis and Klebsiella pneumonia compared with the control.

Form these results we conclude that cortex extract (cxt) of Cucurbita pepo may contains the main specific components that responsible for antimicrobial effect on gram positive Staphylococcus aureus. This means that these components may react specifically with murine layer in gram positive bacteria since moderate and low effect were seen on gram negative bacteria. The fruit core not contains any antimicrobial component therefore not showed any antimicrobial effect on the four tested pathogenic bacteria. When the whole fruit extract used, only moderate and low effect was seen on Staphylococcus aureus and Escherichia coli. This low effect (compared with ctx) may be due to the interaction between the components of cortex and core thereby leads to reduce the effect of cortex components. 
Table 1: Multi-resistance pattern strains and their frequencies used as tested bacteria.

\begin{tabular}{|c|c|c|c|c|c|c|c|c|c|c|c|c|c|c|c|c|}
\hline \multirow[t]{2}{*}{ Bacteria } & \multirow{2}{*}{$\begin{array}{c}\text { Number of } \\
\text { resistant } \\
\text { antibiotics }\end{array}$} & \multirow{2}{*}{$\begin{array}{c}\text { Frequency } \\
\text { and } \\
\text { frequency } \\
(\%)\end{array}$} & \multicolumn{14}{|c|}{ Patterns of Multi-resistance strains } \\
\hline & & & Amp & Aml & Amc & Car & Te & $\mathbf{O t}$ & Do & Sxt & Cn & $\mathrm{Na}$ & $\mathbf{F}$ & $\mathbf{E}$ & $\mathbf{O b}$ & $\mathrm{Cr}$ \\
\hline P. mirabilis & 12 & $2(13.33)$ & Amp & Aml & Amc & Car & $\mathrm{Te}$ & $\mathrm{Ot}$ & Do & Sxt & -- & -- & $\mathrm{F}$ & $\mathrm{E}$ & $\mathrm{Ob}$ & $\mathrm{Cr}$ \\
\hline \multirow[t]{2}{*}{ K.pneumonia } & 13 & $3(20)$ & Amp & Aml & Amc & Car & $\mathrm{Te}$ & $\mathrm{Ot}$ & Do & Sxt & -- & $\mathrm{Na}$ & $\mathrm{F}$ & $\mathrm{E}$ & $\mathrm{Ob}$ & $\mathrm{Cr}$ \\
\hline & 12 & $2(13.33)$ & Amp & Aml & Amc & Car & $\mathrm{Te}$ & $\mathrm{Ot}$ & Do & -- & -- & $\mathrm{Na}$ & $\mathrm{F}$ & $E$ & $\mathrm{Ob}$ & $\mathrm{Cr}$ \\
\hline \multirow[t]{2}{*}{ S. aureus } & 13 & $4(2.1)$ & Amp & Aml & Amc & Car & $\mathrm{Te}$ & $\mathrm{Ot}$ & Do & Sxt & $\mathrm{Cn}$ & $\mathrm{Na}$ & - & $\mathrm{E}$ & $\mathrm{Ob}$ & $\mathrm{Cr}$ \\
\hline & 12 & $2(1.02)$ & Amp & Aml & $\begin{array}{ll}--- \\
\end{array}$ & Car & $\mathrm{Te}$ & $\mathrm{Ot}$ & Do & Sxt & $\mathrm{Cn}$ & $\mathrm{Na}$ & - & $E$ & $\mathrm{Ob}$ & $\mathrm{Cr}$ \\
\hline \multirow[b]{2}{*}{ E. coli } & \multirow[t]{2}{*}{13} & $7(3.58)$ & Amp & Aml & Amc & Car & $\mathrm{Te}$ & $\mathrm{Ot}$ & Do & Sxt & $\mathrm{Cn}$ & $\mathrm{Na}$ & - & $E$ & $\mathrm{Ob}$ & $\mathrm{Cr}$ \\
\hline & & $6(3.07)$ & Amp & Aml & Amc & Car & $\mathrm{Te}$ & $\mathrm{Ot}$ & Do & Sxt & --- & $\mathrm{Na}$ & $\mathrm{F}$ & $\mathrm{E}$ & $\mathrm{Ob}$ & $\mathrm{Cr}$ \\
\hline
\end{tabular}

Ampicillin (Amp), Amoxicillin (Aml), Augmenten (Amc), Carpencillin (Car), Tetracyclin (Te), Oxytetracyclin (Ot), Deoxytetracyclin (Do), Suphamethoxazol (Sxt), Gentamycin (Cn), Naldixic acid (Na), Nitrofurantoin (F), Erythromycin (E), Cloxacillin (Ob), Cephaloridin (Cr).

Table 2: Inhibition zone (mm) of cortex, core and whole fruit extracts.

\begin{tabular}{|c|c|c|c|c|c|c|c|c|}
\hline \multirow{2}{*}{ Bacteria } & \multicolumn{2}{|c|}{ Cortex } & \multicolumn{2}{c|}{ Core } & \multicolumn{2}{c|}{ Whole fruit } & \multicolumn{2}{c|}{ Control } \\
\cline { 2 - 10 } & Aqex & Aex & Aqex & Aex & Aqex & Aex & Amo & Cn \\
\hline Staph. aureus & 10 & 16 & ---- & ---- & 6 & 8 & 18 & \\
\hline E. coli & 4 & 6 & ---- & ---- & 2 & 2 & & 20 \\
\hline $\begin{array}{c}\text { Proteus } \\
\text { mirabilis }\end{array}$ & 2 & 2 & ---- & ---- & ---- & ---- & & 18 \\
\hline $\begin{array}{c}\text { Klebsiella } \\
\text { pneumonia }\end{array}$ & 2 & 2 & ---- & ---- & ----- & ----- & & 18 \\
\hline
\end{tabular}

Aqex=aqueus extract, Aex= Alcoholic extract

Amoxicillin (Amo), Gentamycin (Cn).

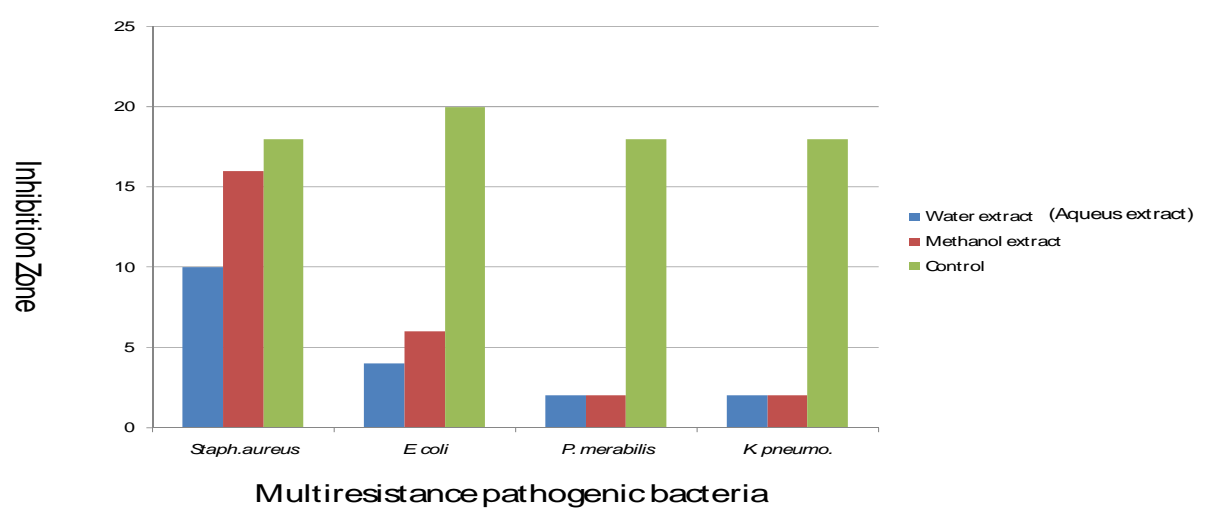

Fig. 1: Antimicrobial activity of Aqueus and alcoholic Cucurbita pepo cortex extract

(Inhibition zone mm) on pathogenic multi-resistant antibiotic strains.

The results obtained from previous study showed that two oil extraction of Cucurbita pepo produced a higher zone of inhibition of $60 \%$ on Staphylococcus aureus and 
Escherichia coli. Phytochemical analyses of Cucurbita pepo extracts reveal the presence of tannins, flavonoids, saponins, cyanogenic glycosides and cardiac glycosides, These extracts, apart from their roles as food additives and supplements, may also be utilized as effective and cheap sources of antibacterial agents for the treatment of bacterial infections (Obi et al., 2009).

\section{CONCLUSIONS AND RECOMMENDATIONS}

The alcoholic and aqueous cortex of Cucurbita pepo possess antibacterial activity against multiresistant pathogenic bacteria that infect the human urinary tract. Cucurbita pepo is available locally and at cheap affordable prices, which will surely enhance their application among other uses, as adjuvant to antibiotics for effective treatment of bacterial infections. These results may suggest that total antimicrobial activities of cortex extract are the come from the individual activities of many components present in the cortex with different effects. It is important to investigate the efficiency of these components in the cortex of Cucurbita pepo with advance methodology to assess the real effect of each component on multiresistant microbes.

\section{REFERENCES}

Ahmed, I.; Edwin, A. K.; Charles, W. W. (1996). Nutrient constituents from eight lines of naked seed squash (Cucurbita pepo L.) J. Agric. Food Chem. 44, 721-724.

Belguith, H.; Kthiri, F. (2010). Inhibitory effect of aqueous extract of Allium Sativum. Afr. J. Mic. Res. 4(5), 328-338.

Cappuccion, J.G.; Sherman, N. N. (1992). "Microbiology Laboratory Manual". The Benjamin cumming publishing Comp. UK, 3rd edn. pp. 408-411.

Chan, E. W.; Lim, Y. Y.; Wong, S. K.; Lim, K. K.; Tan, S. P.; Lianto, F. S.; Yong, M. Y. (2009). Effects of different drying methods on the antioxidant properties of leaves and tea of ginger species. Food Chem., 113, 166-172.

Cheesbrough, M. (2002). "District laboratory Practice in Tropical Countries". Part 2: Cambridge University press UK. pp. 136-142.

Dorman, H. J. D.; Peltoketo, A.; Hiltunen, R.; Tikkanen, M. J. (2003). Characterization of the antioxidant properties of de-odourised aqueous extracts from selected Lamiaceae herbs. Food Chem., 83, 255-262.

Ehinmidu, J. O. (2003). Antibiotics susceptibility patterns of urine bacterial isolates in Zaria, Nigeria. Trop. J. Pharm. Res. 2, 223-228.

Fu, C .; Shi, H .; Li, Q. (2006). A Review on pharmacological activities and utilization technologies of pumpkin. Plant Food for Hum. Nut. 61(2), 70-77.

Godoy, H. T.; Rodriguez-Amaya, D. B.(1998). Occurrence of cisisomers of provitamins A in Brazilian vegetables. J. Agric. Food Chem, 46, 3081-3086

Landrum, J. T.; Bone, R. A. (2001). Lutein, zeaxanthin, and the macular pigment. Arch Biochem Biophys. 385, 28-40.

Leman, T.; Hulya, K.; Raziye, O. (2007). In vitro antioxidant properties of Cucurbita Pepo. Male and female flowers extracts. Plant Foods for Hum. Nut. 62, 49-51.

Maeda, N.; Kokai, Y. (2009). Inhibitory effect of preventive and curative orally administered spinach glycoglycerolipid. J. Food Chem. 112, 205-210. 
Nicodim, I .; Gheorghe, R.; Sorin, R.; Flore, C.; George, C. (2009). Antibacterial effect of essential vegetal extracts on Staphylococcus aureus compared to antibiotics. Notulae Botanicae Horti Agrobotanici Cluj-Napoca, 37, 2.

Obi, K.R.; Nwanebu, F.C. (2009). Antibacterial qualities and phytochemical screening of the oil extract of cucurbita pepo. J. Med. Plant Res. 3(5), 429-432.

Powers, R. D. (1991). New direction in the diagnosis of urinary tract infections, Am. J. Obst. Gynecol, 164, 1387-1389.

Sherif, E. A.; Badr, M. Sh.; Yehya, M. Elkholy ; Maher H.; Helal, A. S.; Hamza, M. S. Masoud.; Mounir M. El Safty (2010). Chemical composition and biological activity of ripe pumpkin fruits (Cucurbita pepo L.) cultivated in Egyptian habitats Natural Product Research: Nat. Prod. Res. DOI: 10.1080/14786410903312991.

Udo E. E.; Al-Sweih, N.; Dhar, R.; Dimitrov, T. S.; Mokaddas, E. M.; Johny, M.; Al-Obaid, I. A.; Gomaa, H. H.; Mobasher, L. A.; Rotimi, V. O.; Al-Asar, A. (2008). Surveillance of antibacterial resistance in Staphylococcus aureus Isolated in Kuwaiti Hospitals. Med. Princ. Prac., 17(1), 71-75. 